\title{
港湾工事に伴う濁りの流動特性に関する実験 \\ AN EXPERIMENTAL STUDY ON CHARACTERISTICS OF SEDIMENT TRANSPORT DUE TO HARBOR CONSTRUCTION
}

\author{
松田信彦 1 松原雄平 $2 \cdot$ 檜谷 $\quad$ 治 ${ }^{3} \cdot$ 黒岩 $\quad$ 正光 $^{4} \cdot$ 山本 貴司 5 \\ Nobuhiko MATSUDA, Yuhei MATSUBARA， Osamu HINOKIDANI, \\ Masamitu KUROIWA, Takasi YAMAMOTO \\ 1正会員 工修 東亜建設工業(侏)（テ102-8451 東京都千代田区四番町5） \\ 2 正会員 工博 鳥取大学教授 工学部土木工学科 (下680-8552 鳥取市湖山町南4丁目101) \\ 3 正会員 工博 鳥取大学助教授 工学部土木工学科（テ680-8552 鳥取市湖山町南4丁目101） \\ 4正会員 工博 鳥取大学助手 工学部土木工学科 (下680-8552 鳥取市湖山町南4丁目101) \\ 5 学生員 鳥取大大学院 工学部土木工学専攻 (テ680-8552 鳥取市湖山町南4丁目101)
}

\begin{abstract}
When we will evaluate an influence on the turbidity due to the harbor construction, it is very important to investigate the behavior of the fine sediment. Earth filling soil contains the fine sand which settling velocity is very low and floats for a long time. Therefore especially the dumped soil by hopper barge can be thought to cause large-scale water pollution around the surface of the water.

In the previous study, the property of settling soil and the flowing characteristics of the muddy water lump after the bottom collision usually have been considered. But, the occurrence mechanism of turbidity to diffuse around the surface of the water just after the injection is hardly being studied. When harbor construction is performed, the turbidity, which usually causes a problem, might be occurred by not only the turbidity from the bottom layer, but also turbidity around the water surface floating for a long time.

Therefore in this research, the turbidity to diffuse around the surface of the water just after the injection is investigated experimentally. Form the experimental results, it is found that the falling fine sediments might be lifted to the water surface due to the bubble way of the air contained in the injection soil.
\end{abstract}

Key Words: Turbidity, hopper barge, muddy water lump

1.はじめに

港湾工事に伴う濁りの流動特性を把握することは, 工事周辺海域の環境への影響を評価する上で非常に 重要である。特に底開バージによる土砂投入は, 水 面付近から多量の土砂を投入するため，投入土砂に 含まれる沈降速度の遅い微細土粒子が長時間投入周 辺の水域に浮遊し, 大規模な水質污濁を引き起こし ていると考えられる.

従来の研究おいては，このような濁りの拡散に対 して, 拡散方程式を用いた解析や密度流的な（乱流 サーマル理論）挙動としてとらえたもの の固体粒子（代表粒子）の運動を個別要素法とMAC 法を組み合わせて誘起流動場の再現を試みたもの4 がある.しかし，従来の研究の多くは，土砂直投に よる濁水塊の沈降特性と底面衝突後の底面に沿う底 層付近の流動特性に着目した研究が多く，土砂投入 直後に水面付近で拡散する濁りの発生メカニズムに
ついてはほとんど研究されていない。港湾工事の施 工時において通常問題になる濁りは，底層付近の濁 りよりもむしろ水辺付近で長時間浮遊している濁り であることが多い。

本研究では, このような土砂投入直後に水面付近 で拡散する濁りを，中立粒子とガラスビーズを用い て実験を行い. 水面付近の濁りの拡散メカニズムを 明らかにするものである。

\section{2. 従来の現地観測結果}

古土井" は昭和59年に関西国際空港建設予定地に おいて地盤改良施工実験を実施した。この際，工事 に伴う濁りの発生拡散等を調査している。図-1は土 運船による二次敷砂投入実験における調査点位置で ある.図-2は，図-1の3 ライン（土砂直投位置から $200 \mathrm{~m}$ 離れた点）における，山砂投入 30 分後の S S の横断面分布である.図-3は，図-2と同じ条件で山 
砂投入 30 分後の S S の縦断面分布である.

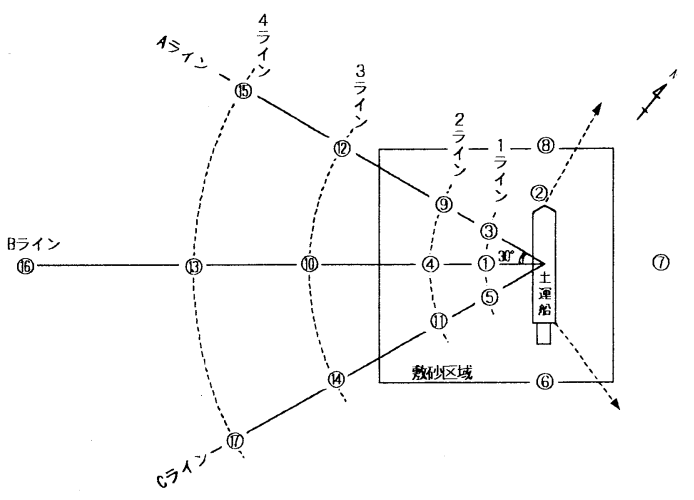

図-1 調查点位置

直投直後に土砂投入により生じた流れ（乱泥流） により底層で急激に拡散する高濃度の濁りは，30分 後には海底面上 $3 \mathrm{~m}$ 程度の厚さで $300 \mathrm{~m}$ 付近まで達し ている。一方，上層の水面下 $5 \mathrm{~m}$ 付近の濁りは，土 砂投入直後は土運船の周囲に気泡とともに浮かび上 がったものが見られる程度で，投入後10分後くらい でようやく上層へ浮かび上がり，低濃度の微細粒子 群が短時間で遠方に拡散する。この上層の濁りは, 横断面，縦断面分布を見て分かるように乱泥流が上 層に現れたものではなく，土砂が海底に達したはね 返りのものと，乱泥流が進んでいくときの分散運動 における濁りの分離，あるいは気泡とともに上昇し たものが主なものと指摘していることから，実験で は気泡と共に上昇する濁りについて実験を行った。

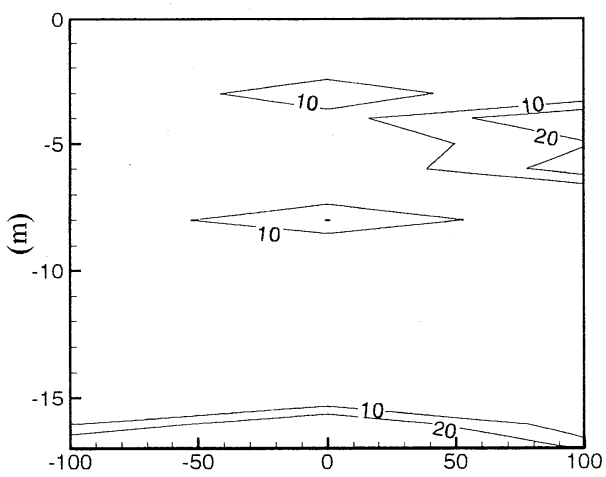

(m)

図-2Ｓ S の横断面分布

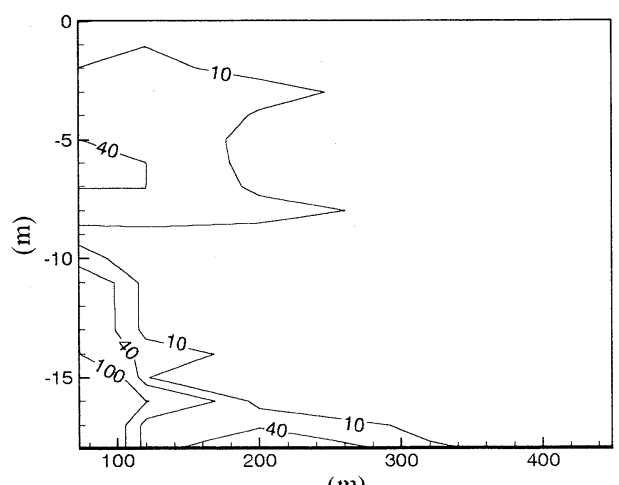

(m)

図-3 S S の縦断面分布

\section{3．実験方法及び実験結果}

従来のシルトなど微細な粒子を使った室内実験で は，現地観測のような上層付近の濁りについては再 現されていない。これは，使用している微細な粒子 の空隙が少ないために，気泡があまり混入されず， 粒子投入後の気泡による上昇流がうまく再現できて いないためだと考えられる。

そこで, 本研究では粒子の空隙中の気泡を, 別 の方法で再現することを考え，投入土砂の沈降速度 に着目して投入土砂をモデル化することにした。投 入土砂に含まれる濁りの拡散粒子に比重が1.01の中 立粒子, 先行して沈降する数十 $\mathrm{cm}$ 程度の石にはガラ スビーズを使用し実験を行った。濁りの拡散粒子に 中立粒子を使用すると，わずかな気泡でも中立粒子 と付着すると，比重が小さくなり上昇するため，実 際と類似した濁りの拡散が再現できる。

実験に使用した粒子は表-1に示す粒子を使用した。 実験粒子の特性值を示しており, d50: 中央粒径, $\rho \mathrm{d}$ : 粒子密度, Ud : 自由沈降速度 (最終沈降速 度)であり，また， Red (=Ud* d50/レ)は粒子レイ ノルズ数, レ : 水の動粘性係数である.

表-1 使用粒子

\begin{tabular}{|c|c|c|c|c|c|}
\hline & 種類 & $\begin{array}{c}\mathrm{d} 50 \\
(\mathrm{~mm})\end{array}$ & $\begin{array}{c}\rho \mathrm{d} \\
\left(\mathrm{g} / \mathrm{cm}^{3}\right)\end{array}$ & $\begin{array}{c}\mathrm{Ud} \\
(\mathrm{cm} / \mathrm{s})\end{array}$ & $\operatorname{Red}$ \\
\hline (1) & ガラスビーズ & 5.0 & 2.50 & 48.4 & 2.418 \\
\hline (2) & 中立粒子 & 5.0 & 1.01 & 2.6 & 132 \\
\hline
\end{tabular}

\section{(1) 実験 1}

はじめに，濁りの拡散は移流の影響を大きく受け るため，土砂投入時の流れ場について詳しく計測す ることにした。

\section{(a) 実験方法}

実験は長さ $22 \mathrm{~m} ，$ 深さ $0.9 \mathrm{~m} ，$ 幅 $0.6 \mathrm{~m}$ の前面ガラ 又張り大型水槽の上部中央付近に図-4に示す投入装 置（長さ $0.55 \mathrm{~m} ，$ 深さ $0.3 \mathrm{~m} ，$ 幅 $0.7 \mathrm{~m}$ ，投入幅 0 . 01m）を水面から $5 \mathrm{~cm}$ のところに設置し， $5 \mathrm{~mm}$ のガラ スビーズ $3 \mathrm{~kg}$ を約8秒間連続投入した。投入装置周辺 の流速は，3次元超音波ドップラ一流速計を用いて 測定した。測定間隔は0.4秒で，測定時間は約 30 秒 である．測定場所は，図-4のように水平方向に投入 装置の直下から $5 \mathrm{~cm}$ 間隔で $10 \mathrm{~cm}$ まで 3 測点と，鉛直方 向に水深 $5 \mathrm{~cm}$ か $5 \mathrm{~cm}$ 間隔で水深 $45 \mathrm{~cm}$ まで 9 測点, 合 計27測点であり，各々の測点で3回計測し，計測結 果はその平均とした。

\section{（b）実験結果}

図-5～10は，投入装置直下の上層（測点 1 ），中 層（測点4），下層（測点9）の3測点における鉛直 流速と水平流速の時間変化を示したものであり，投 入場所付近では, 気泡やガラスビーズによる変動が 大ききため，1秒間の移動平均流速にしている。一 方，図-11，図-12は，測定結果を流速べクトル図に したもので，測定值の変動を抑えるために，4秒間 
の平均流速を使用している.

まず，投入中の流れについてみると，投入場所で は投入粒子によって投入直後から速い下向きの流れ が誘起されていることがわかる。しかしながら，こ の下向きの流れは，投入投入中に徐々に弱まる傾向 にある。一方，投入位置の外側では，下降流を補う 投入位置に向かう水平方向の流れが発生している. また，底面付近では，底面に衝突した下降流が左右 に向きを変えて流れている様子がわかる。

つぎに，投入後の流れに注目する。投入粒子によ る下向きの誘起流は，投入完了後8-12秒で上部から 急激に減少している。この後, 上層ではガラスビー ズと一緒に連行された気泡の上昇により発生した流 れにより，上向きの流れが発生している。この上昇 流によって微細土砂粒子が上昇すれば, 水面付近で 高濃度域が発生する．特に現地での土運船による土 砂投入では，水深が大きく，気泡が上昇する時間が 10分以上である場合が多い。その場合，土砂の投入 が完了し，実験で見られたように上層から下降流が 急激に減少すると, 沈降途中の微細な土粒子が停滞 することなる，そこに気泡と共に大きな上昇流が発 生すれば大量の濁りが，短時間で水面まで運ばれる 可能性がある.

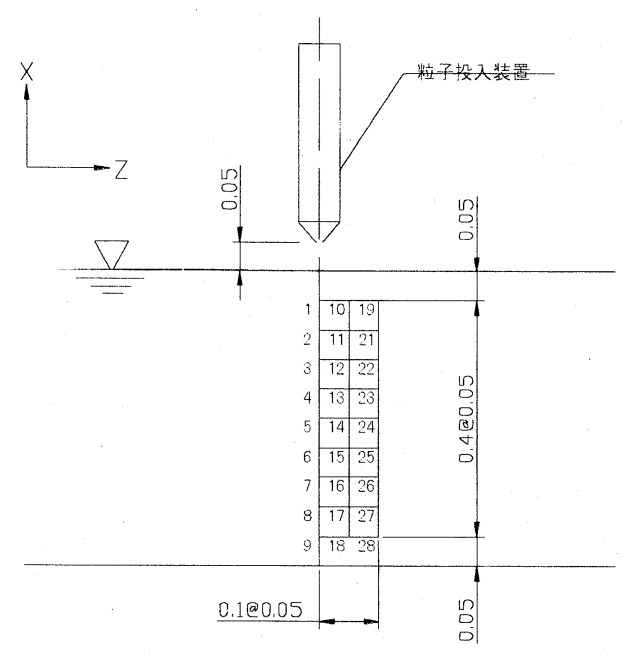

図-4 测定位置図

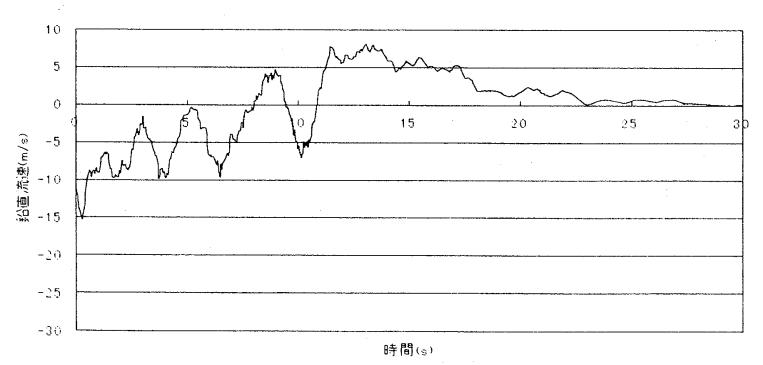

図-5 測点 1 鉛直流速変化

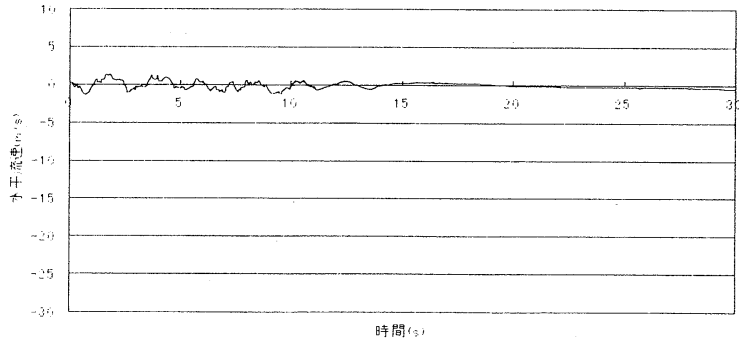

図-6 測点 1 水平流速変化

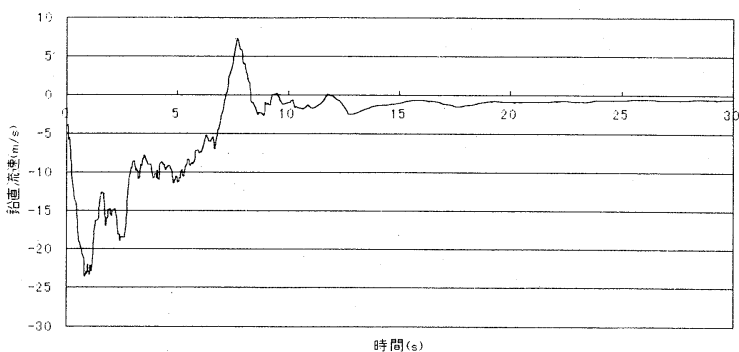

図-7 測点 4 鉛直流速変化

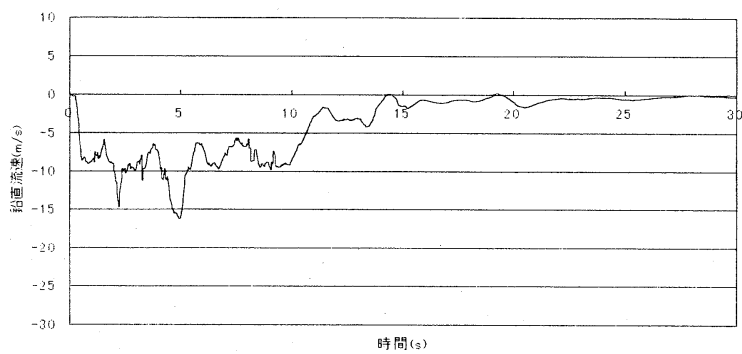

図-8 測点 4 水平流速変化

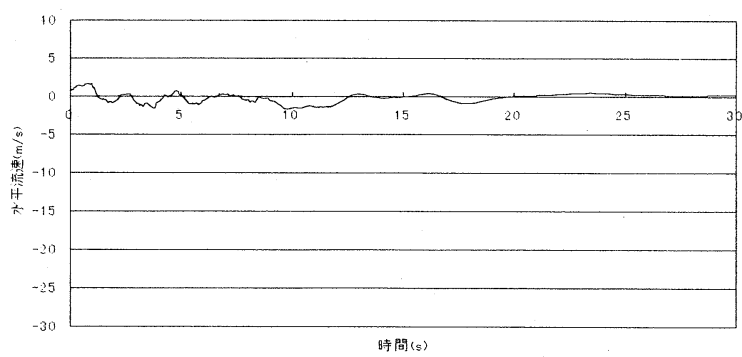

図-9 測点 9 鉛直流速変化

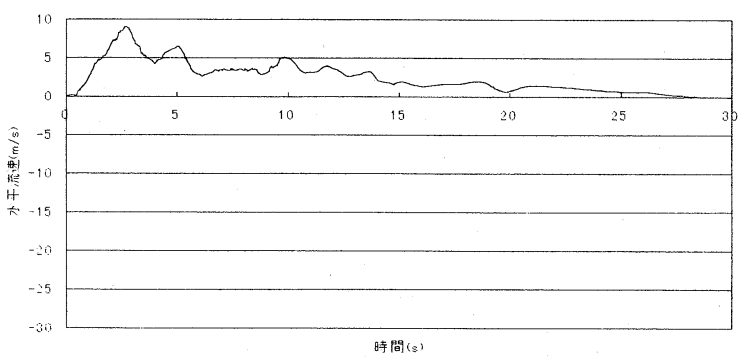

図-10 測点 9 水平流速変化 

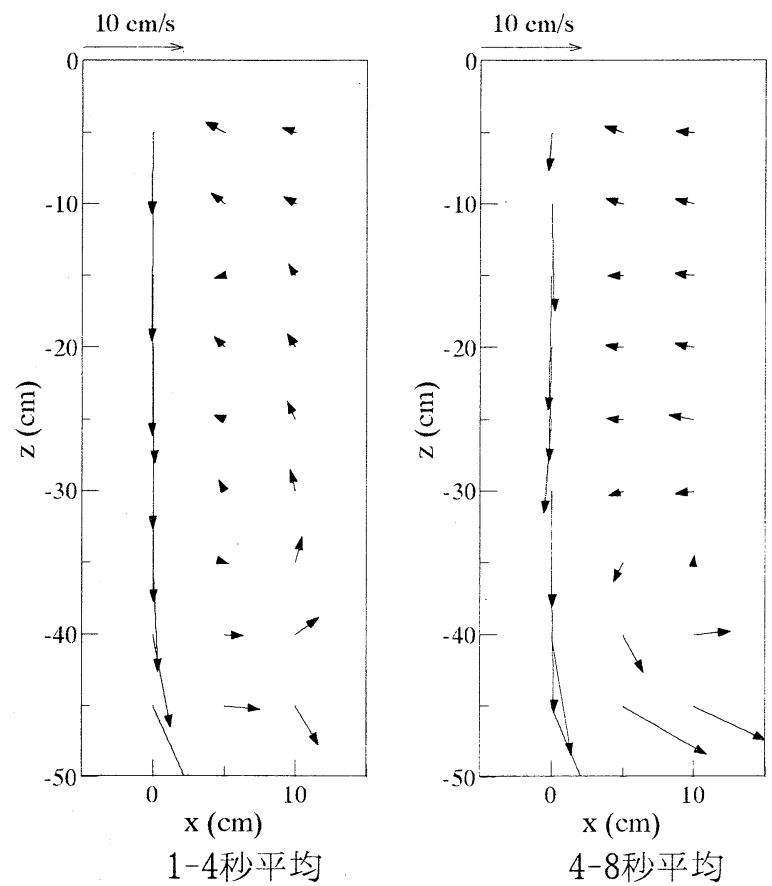

図-11 投入後の流速ベクトル庹
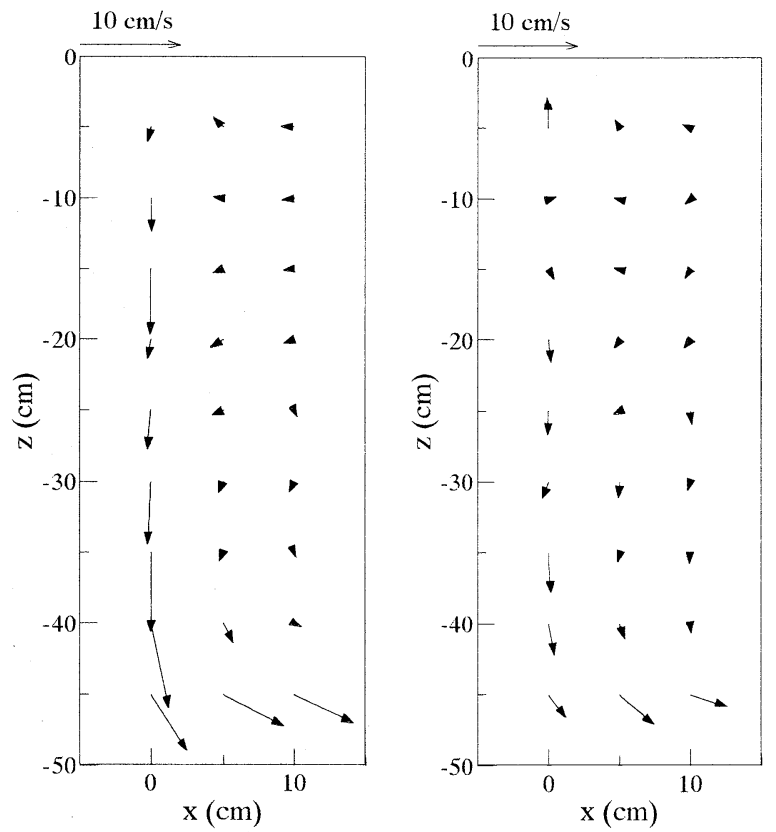

8-12秒平均 付けたものである．5mmガラスビーズと中立粒子を 合計 $40 \mathrm{~cm}^{\natural}$ になるように $1: 1$ で混合した。粒子の投入 時間は平均 0.8 秒で水面から $5 \mathrm{~cm}$ の高さから投入装

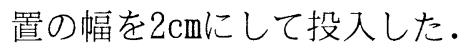

粒子運動の測定にはビデオカメラを用いて，図一 14のようなLWHについて中立粒子を計測した。今回 の実験では, 初期の水面付近での拡散現象を調べる 事を目的としているので，ガラスビーズが水槽の底 についた時点で計測を終了する。また，現象のばら つきを押さえるため，同じ実験を3回行った。

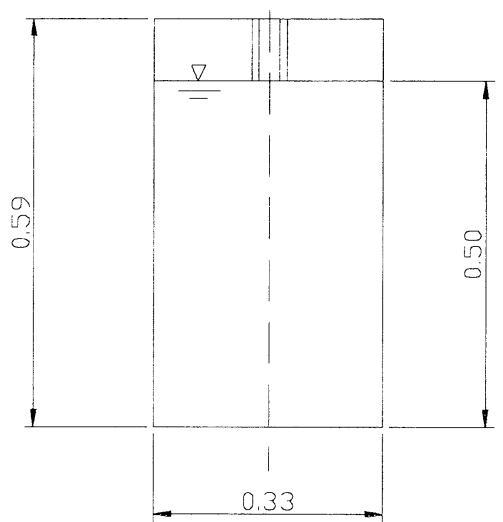

図-13 実験水槽

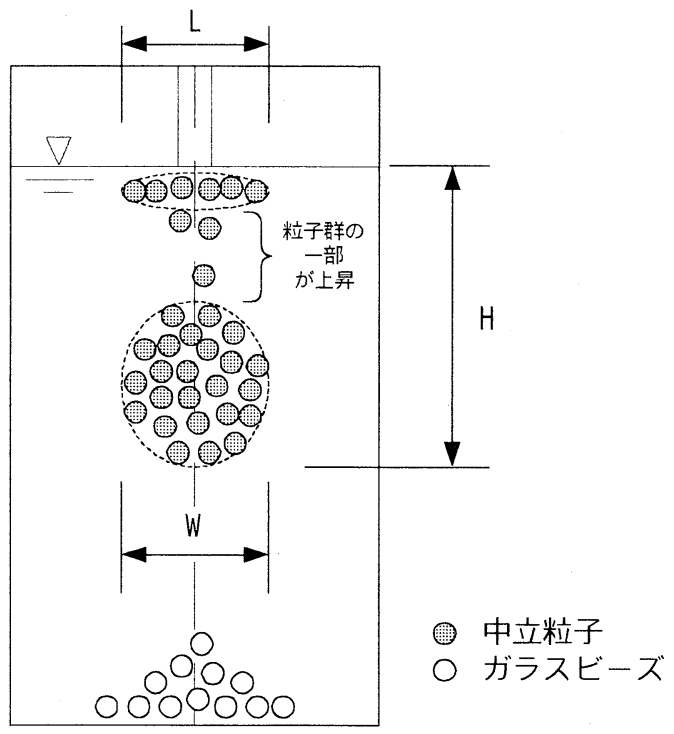

図-14 中立粒子の測定方法

\section{（b）実験結果}

写真-1は粒子投入 2 秒後の様子である.中立粒子 の一部はガラスビーズの誘起流に乗って1度沈降し てから，水面に浮上してくる状態を撮影したもので ある. 中立粒子が上昇するには，投入時に連行され た気泡の上昇流によるものと, 小さい気泡が中立粒 子に付着して上昇する 2 通りが考えられる. 中立粒 子に気泡が付着すると, 比重が軽くなり上昇してい る粒子もある。実際に土粒子に気泡が付着して浮上 することは考えられないが，中立粒子が，微細な土 
粒子と気泡が一緒になっていると考えると，現実に 近い挙動をしているとして考えられる。

まず，全体的な中立粒子の沈降特性を見たものが 図-15であり，沈降する中立粒子梼の先端位置の壯 間的変化をあらわしたものである。中立粒子とガラ スビーズを混ぜて投入すると，ほぼ一塊となって沈 降し, 単体で沈降するときよりかなり早い速度で沈 降することがわかる。

-一方，図一16は水面付近に浮にした中方粒了の搪 散を調べたものである。水面付近の桩散速度は $3 \mathrm{~cm} / \mathrm{s}$ 以上で，水平流が発生していると考えられる。

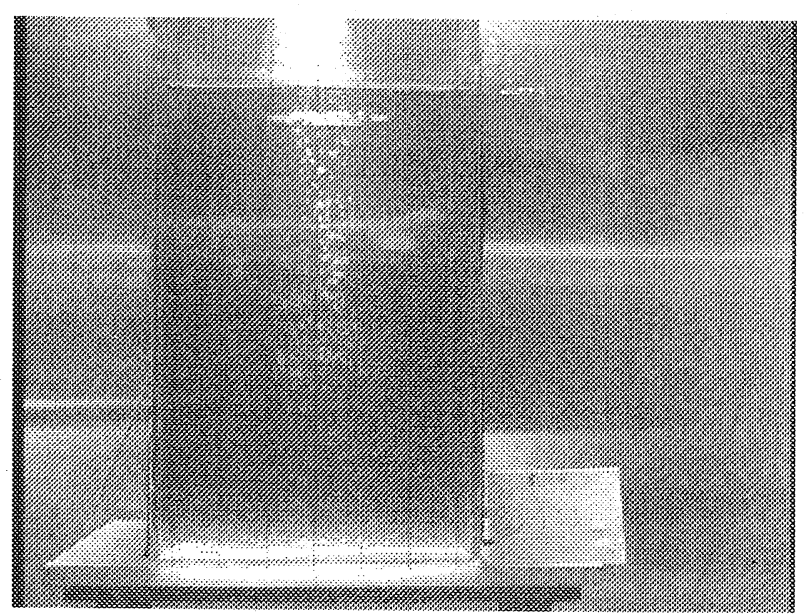

写真-1 粒子投入2秒後の様子

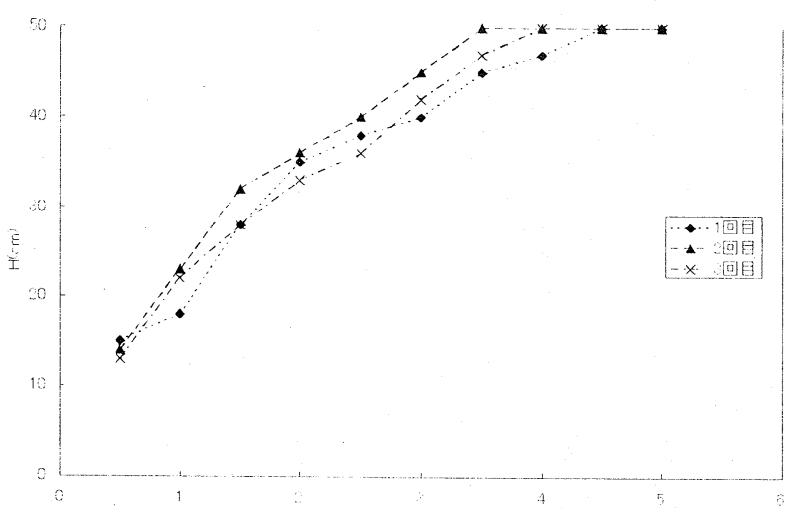

図-15 中立粒子の沈降距離と時間の関係

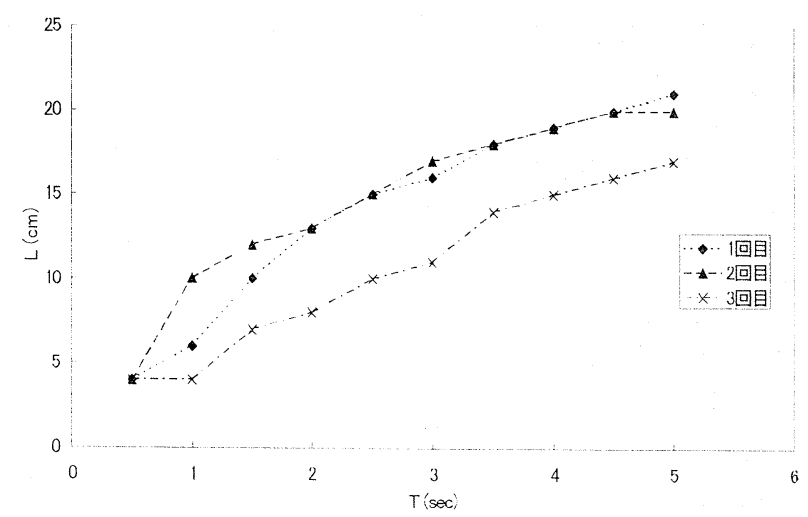

図-16 中立水面付近の去がりと咕間の関係

\section{4. 中立粒子の妥当性について}

中立粒子の妥当性を検討するために，微細粒子 （8号珪砂）と投入状沉の比較した。実験は実験 1 と同様の条件で， $5 \mathrm{~mm}$ のガラスビーズ $3 \mathrm{~kg} に ，$ $1,000 \mathrm{cc}$ の珪砂と中立粒子をそれぞれ混合して投入 したものである。

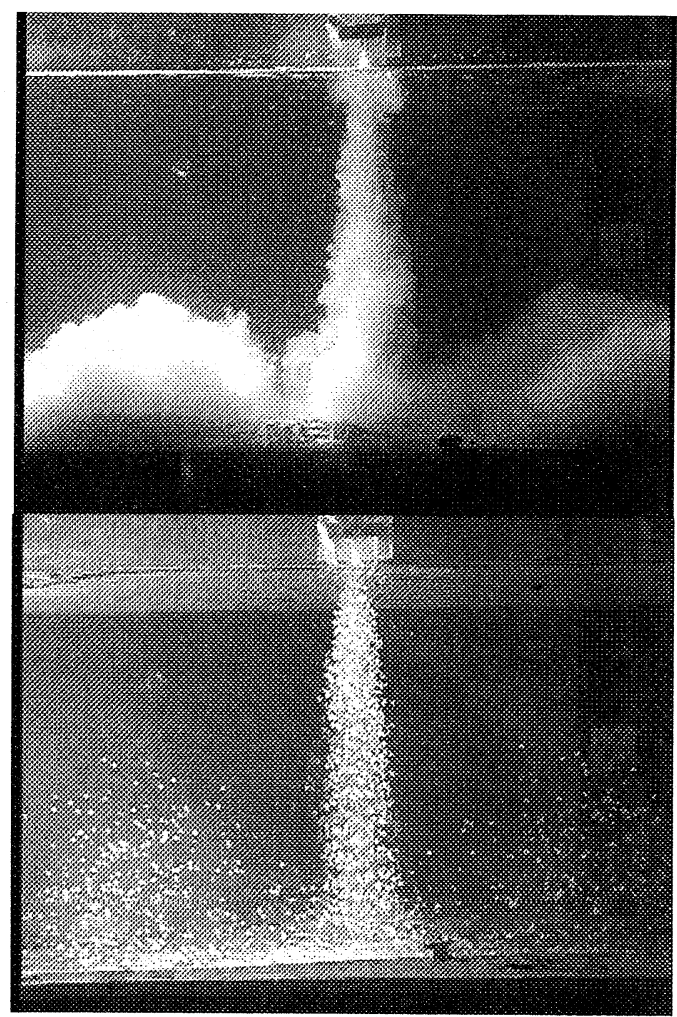

写真-2 投入開始6秒後 上：珪砂，下：中立粒子

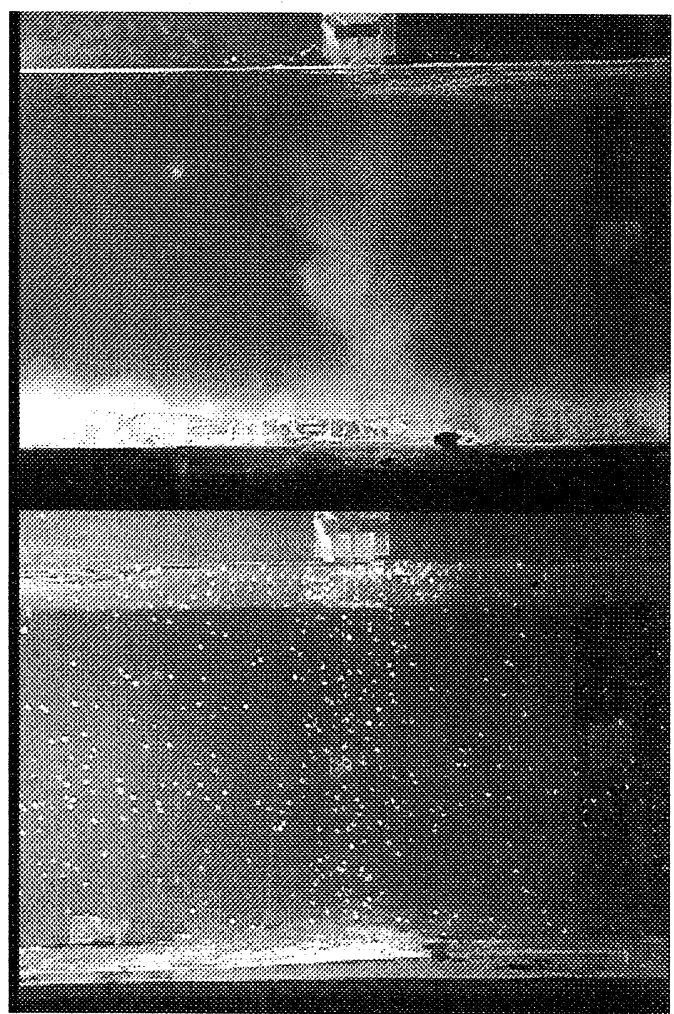

写真-3 投入開始 26 秒後 上: 珪砂，下: 中立粘子 
写真-2および写真-3はそれぞれの実験の投入後 6 秒 後と 26 秒後の状況を比較したものである。まず，投 入中の6秒後の状態を比較すると両者は非常に類似 した拡散をしている。したがって，中立粒子を微細 粒子とした実験もある程度実際の現象を表現できて いるものと考えられる。

つぎに，写真-3は拡散状況を比較したものである が, 沈降速度の違いによって大きく状況が異なって おり, 沈降速度の速い珪砂は停滞しているのに対し, 気泡が付着し沈降速度が遅くなつている中立粒子は 上昇している。したがって，投入後に微細粒子が水 面付近に浮上するかどうかは微細粒子の沈降速度と 土砂投入に伴って発生する気泡による上昇流の比に よって決まる現象であると考えられる。

\section{5. 水面付近の濁りの発生メカニズム}

本研究で得られた実験結果から推定した水面付近 の濁りの発生メカ二ズムをまとめると以下のようで ある。

\section{（1）上層の濁りの発生源}

上層の濁りとしては, 沈降中の微細粒子が上層で 分離し停滞したもの, 乱泥流により底泥が巻上げら れたもの，海底に達した土砂がはね返り上昇したも の, 乱泥流が進んでいくときの分散運動における濁 水塊からの分離し上昇したものが考えられる.

\section{（2）濁りの動き}

停滞している微細土粒子の上昇については，投入 完了後の微細土粒子の沈降時間と上昇流が発生して いる時間が重要であると考えられる。

今回の実験では水深が浅く，実際の粒子より中立 粒子の沈降速度が速いため, 気泡による上昇流が発 生するまでに，ほとんどの中立粒子が沈降している。

しかしながら，実際の土運船による投入では水深 が大きいので，実験 1 のように投入後に短時間で土 砂による下向きの誘起流が小さくなれば，沈降中の 微細土粒子が沈降途中で停滞する.一方, 気泡は投 入中に連行されるものと，土砂の間隙に含まれる空 気が土砂の着底後に時間をかけて上昇するものが考 えられるが，おそらく後者の土砂に含まれる空気が， 土砂による誘起流が小さくなってから, 長時間気泡 を発生させ，これにより停滞していた微細土粒子が 流れに乗って水面付近に持ち上げられると考えられ る.

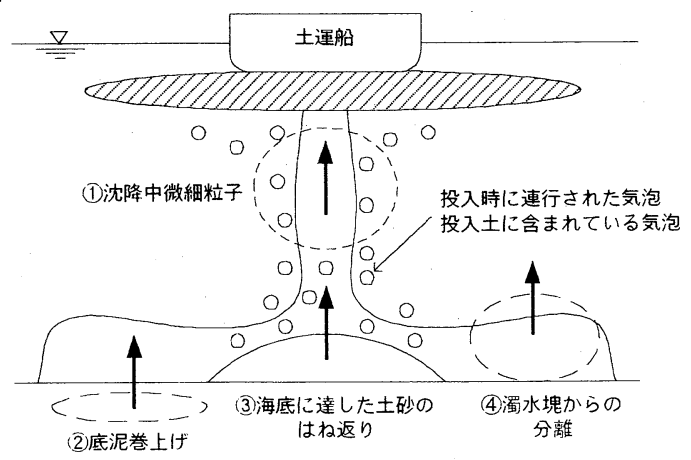

図-17 上層の濁りの発生源
メカニズムを概念図で示したものが図-17である。

\section{6. まとめ}

本研究は，土運船で土砂投入をする際，水面付近 で長時間浮遊する粒子の運動に着目し実験を試みた。 実験結果より，上層の濁りは，土運船による投入完 了後, 土砂による誘起流が急激に小さくなり，沈降 中に停滞した微粒子が，投入土砂の間隙に含まれる 空気の気泡流により水面付近に持ち上げられるのが 主な要因と考えられる.今後, 土砂投入時の底開 バージ周辺の流れについて，現地観測を行い上昇流 について詳しく調査する予定である。

\section{参考文献}

1)古土井 光昭：港湾工事における濁りの挙動に関する 研究, 大阪大学学位論文, 1989 .

2) 玉井 昌宏, 分散相誘起型混相流の流動・乱流構造に 関する研究, 大阪大学学位論文, 1994 .

3)玉井 昌宏, 村岡 浩爾, 固体粒子群の落下挙動と誘 起流動に関する解析, 海岸工学論文集, No. 39, pp. 961-965， 1992 .

4) 小田一紀, 重松 孝昌, 大西 伸幸, 井上 雅夫, 改 良型DEMAC法による粒子群の沈降・分散挙動の解析, 海 岸上学論文集, No. 39, pp. 971-975, 1992. 